Original Article

\title{
FORMULATION AND EVALUATION OF PECTIN-CALCIUM CHLORIDE BEADS OF AZATHIOPRINE FOR COLON TARGETED DRUG DELIVERY SYSTEM
}

\author{
SAMIR A. ATARA ${ }^{*}$, MOINUDDIN SONIWALA ${ }^{2}$ \\ 1Ph.D. Scholar, Associate Professor, School of Pharmacy, RK University, Rajkot, Gujarat, India. ${ }^{2}$ Associate Professor, B. K. Mody Govt. \\ College of Pharmacy, Rajkot, Gujarat, India \\ Email: samir.atara@rku.ac.in \\ Received: 16 Oct 2017 Revised and Accepted: 22 Nov 2017
}

ABSTRACT

Objective: Calcium pectinate is an insoluble hydrophilic material used for sustained release delivery. The objective of the study was formulation and evaluation pectin-calcium chloride beads of azathioprine.

Methods: Calibration curves of azathioprine were prepared in $0.1 \mathrm{~N} \mathrm{HCl}$ solution (pH-1.2) and phosphate buffer (pH-6.8 and pH-7.4). Fourier transform infrared spectroscopy and differential scanning calorimetry was used to determine compatibility between azathioprine and excipients. Formulation and optimization of calcium-pectinate beads were performed. The coating of the optimized batch was performed with eudragit S100. Micrometric properties, scanning electron microscopy, in vitro azathioprine release, and stability study was performed. Dissolution kinetic study was assessed for various kinetics models of the optimized batch. The Wilcoxon test followed by the Dunnett's multiple comparison tests were performed between uncoated and coated beads in vitro dissolution profile of optimized batch in $0.1 \mathrm{~N} \mathrm{HCl} \mathrm{after} 2 \mathrm{~h}$.

Results: Fourier transform infrared spectroscopy and differential scanning calorimetry had identical peaks with that of pure azathioprine in compatibility study. Scanning electron microscopy of an uncoated optimized batch of beads indicated the smooth and uniform surface of prepared beads. Eudragit S100 coating was decreased release of azathioprine release in $0.1 \mathrm{~N} \mathrm{HCl}$ after $2 \mathrm{~h}(p=0.049, q=3.533)$. Korsmeyer/Peppa's model was applied with release exponent higher than 1 . In vitro percentage cumulative azathioprine release was identical before and after stability study.

Conclusion: Calcium pectinate beads of azathioprine, a multi-particulate dosage form using pH-dependent approaches were prepared.

Keywords: Azathioprine, Bead, Calcium carbonate, Eudragit S100, Pectin

(C) 2018 The Authors. Published by Innovare Academic Sciences Pvt Ltd. This is an open access article under the CC BY license (http://creativecommons.org/licenses/by/4.0/) DOI: http://dx.doi.org/10.22159/ijpps.2018v10i1.23175

\section{INTRODUCTION}

Inflammatory bowel disease (IBD) is a collective term encompassing related but distinct chronic inflammatory disorders of the gastrointestinal tract such as Crohn's disease, ulcerative colitis, indeterminate colitis, microscopic colitis, and collagenous colitis [1]. In IBD, colon-specific drug delivery system is preferred dosage form because of having advantages of oral administration and site-specific action [2]. Colon targeted drugs are more effective in fewer dose [3].

Pectin is a purified polysaccharide obtained from the diluted acid extract of the inner portion of the rind of citrus fruits or from apple pomace. It consists chiefly of partially methoxylated polygalacturonic acids. The galacturonic acid residues which have carboxyl groups are present as methyl esters. Low methoxy pectin (with a degree of esterification $<50 \%$ ) from rigid gels by the action of calcium which cross-links the galacturonic acid chains. Since pectin can react with calcium ions forms calcium pectinate as an insoluble hydrophilic material used for sustained release delivery [4].

The objective of the study was to formulate and optimize pectincalcium chloride beads of azathioprine, compatibility study, coating with eudragit S100, and to evaluate micrometric properties, scanning electron microscopy, in vitro azathioprine release, and stability.

\section{MATERIALS AND METHODS}

\section{Material}

Azathioprine was purchased from Troikka pharma, Ahmedabad India. Pectin and eudragit S100, disodium hydrogen phosphate, potassium dihydrogen phosphate, hydrochloric acid $(\mathrm{HCl})$ were purchased from Oxford Lab., Mumbai, India. Calcium chloride $\left(\mathrm{CaCl}_{2}\right)$ was purchased from Chem. Lab. India.

\section{Calibration curve for azathioprine}

There was $10 \mu \mathrm{G} / \mathrm{ml}$ solution of azathioprine prepared in $0.1 \mathrm{~N}$ $\mathrm{HCl}$ solution (pH-1.2) and phosphate buffer ( $\mathrm{pH}-6.8$ and $\mathrm{pH}-7.4)$. It was scanned using UV Spectrometer $(1700 \mathrm{UV} /$ Vis double beam, Shimadzu, Japan) and absorbance maximum $\left(\lambda_{\max }\right)$ was noted in all medium.

There were different solutions $(2-30 \mu \mathrm{G} / \mathrm{ml})$ of it in different medium were prepared and absorbance was noted at $\lambda_{\max }$. Calibration curves of azathioprine were prepared in $0.1 \mathrm{~N} \mathrm{HCl}$ solution (pH-1.2) and phosphate buffer ( $\mathrm{pH}-6.8$ and $\mathrm{pH}-7.4)$.

Compatibility studies between azathioprine and excipients

Fourier transform infrared spectroscopy (FTIR) and differential scanning calorimetry (DSC) was used to determine compatibility between azathioprine and excipients.

\section{DSC study}

The samples of pure azathioprine and azathioprine-pectin mixtures were prepared to investigate the molecular state of the azathioprine using differential scanning calorimeter (DSC-60, Shimadzu, Japan). Each sample was sealed in an aluminum pan and heated at a constant rate $\left(10.0^{\circ} \mathrm{C} / \mathrm{min}\right)$ over a temperature range of $10-350{ }^{\circ} \mathrm{C}$ under a nitrogen purge of $20 \mathrm{ml} / \mathrm{min}$ [5].

\section{FTIR study}

FTIR (Shimadzu, Japan) was performed for qualitative and structural identification of azathioprine and azathioprine-pectin mixtures. Each sample was placed in the compartment and identical spectrum was generated. Comparisons were carried out between the spectrum of pure azathioprine and azathioprinepectin mixture [6]. 


\section{Formulation and optimization of calcium-pectinate beads}

Pectin was dissolved in distilled water with continues agitation. Azathioprine was added into it and with continuation agitation allowed to stand overnight. Azathioprine pectin dispersion was added to the $\mathrm{CaCl}_{2}$ solution and provided $2 \mathrm{~h}$ for hardening at $60^{\circ} \mathrm{C}$ of drying for $3 \mathrm{~h}$ [7]. Process parameters such addition rate 1 $\mathrm{ml} / \mathrm{min}$, stirring speed $20 \mathrm{rpm}$, and nozzle diameter $0.4 \mathrm{~mm}$ were kept constant during the process. Different batches of beads were prepared as per table 1 .

Table 1: Formulations of pectin beads

\begin{tabular}{lll}
\hline Batch no. & Ratio of pectin: $\mathbf{C a C l}_{\mathbf{2}}$ & Azathioprine (mg) \\
\hline A1 & $1: 1$ & 600 \\
A2 & $1: 1.5$ & 600 \\
A3 & $1: 2$ & 600 \\
A4 & $1.5: 1$ & 600 \\
A5 & $1.5: 1.5$ & 800 \\
A6 & $1.5: 2$ & 800 \\
A7 & $2: 1$ & 800 \\
A8 & $2: 1.5$ & 800 \\
\hline
\end{tabular}

*Optimized batch

\section{Coating method}

The coating operation was performed on fluid bed coater (Remi equipment, Mumbai, India). There were $50 \mathrm{~g}$ beads of the optimized batch were taken into the coating vessels. Blower and heater were switched on to achieve the required temperature. The coating solution of required strength was prepared and visual examination was done for clarity of the solution. Once all the preliminary preparation was satisfactory, fluid bed coater was started to accomplish the coating process. After completion of the process, coated beads were weighted to evaluate coating efficiency. During process parameters, inlet air temperature $45^{\circ} \mathrm{C}$, outlet air temperature $37-40{ }^{\circ} \mathrm{C}$, atomizing air pressure 1.25 $\mathrm{kg} / \mathrm{cm}^{2}$, blower speed $900 \mathrm{rpm}$, and spray rate $2 \mathrm{ml} / \mathrm{min}$ were kept constant. Three different batches from optimized batch were prepared according to different times of coating as $20 \mathrm{~min}$ (D1), 40 min (D2), and $60 \mathrm{~min}$ (D3).

\section{Micrometric properties of beads}

\section{Production yield (percentage yield)}

Loading amount of pectin and weight of the dried beads of each batch were accurately measured. Production yield (percentage yield) was determined as per equation Eq. 1 . Due care was taken to avoid experimental weight loss of beads during the preparation [1].

$$
\text { Production Yield (\% Yield })=\frac{\text { Total mass of beads }}{\text { Total mass of raw material }} \times 100(1)
$$

\section{Morphology of beads}

The spherical shape of the beads was one of the crucial parameters as it influenced on various other parameters. Properly dried beads of each batch were visually observed and morphological effects of pectin concentration and $\mathrm{CaCl}_{2}$ concentrations were studied [1].

\section{Loss of weight during drying (LOD)}

Beads were weighted before and after the drying process to determine percentage weight loss as per the Eq. 2. Due care was taken to avoid experimental weight loss of beads during the preparation [1].

$$
\% \text { Weight loss }=\frac{\mathrm{W}_{\mathrm{t}}-\mathrm{W}_{\mathrm{o}}}{\mathrm{W}_{\mathrm{t}}} \times 100 \ldots \ldots(2)
$$

Where,

$$
\mathrm{W}_{0}=\text { Weight of dried beads }
$$$$
\mathrm{W}_{\mathrm{t}}=\text { Weight } \text { of undried beads }
$$

\section{Determination of swelling index}

There were $10 \mathrm{~g}$ of dried beads dipped in a beaker containing 100 $\mathrm{ml}$ of $0.1 \mathrm{~N} \mathrm{HCl}$ solution. The swollen beads were weighted at specified time intervals. After $30 \mathrm{~min}$, there was increased in the weight of beads which was considered as the end of the experiment. Following Eq. 3 was used to determine the swelling Index [1].

$$
\text { Swelling Index }=\frac{W_{a}-W_{b}}{W_{a}} \times 100
$$

Where,

Wa $=$ Initial weight of dried beads,

$\mathrm{Wb}=$ The weight of beads at time $\mathrm{t}$.

\section{Physical properties of beads}

The study was designed as following to identify the compressibility, flowability and particle size of prepared beads.

\section{Determination of average particle size of beads}

Average bead size was determined by optical microscopy method. The properly dried bead was placed on a glass slide which was mounted on the stage of the microscope (Olympus, India). The calibrated ocular micrometre (Olympus, India) was used to measure the diameter of 50 dry beads and mean particle size was calculated [8].

\section{Bulk density}

Accurately weighted beads were poured into measuring cylinder and tapped for three times. The volume occupied by beads was measured, known as bulk volume. The bulk density was determined as per Eq. 4 [8].

$$
\text { Bulk density }=\frac{\text { Weight of beads }}{\text { Bulk volume of beads }}(4)
$$

\section{Tapped density}

Accurately weighted beads were poured into measuring cylinder and tapped until the height of beads became constant. The volume occupied by beads was measured, known as tapped volume. Tapped density was determined as per Eq. 5 [8].

$$
\text { Tapped density }=\frac{\text { Weight of beads }}{\text { Tapped volume of beads }}(5)
$$

\section{Determination of flow properties}

Percentage compressibility index and Hausner ratio were determined as per the Eq. 6 and 7, respectively [8].

$$
\begin{gathered}
\% \text { Compressibility Index }=\left(1-\frac{V_{o}}{V}\right) \times 100(6) \\
\text { Hausner's ratio }=\frac{V_{o}}{V} \text { OR } \frac{\rho_{o}}{\rho}(7)
\end{gathered}
$$

Where,

$\mathrm{V}=$ Tapped volume,

$\mathrm{V}_{0}=$ Bulk Volume, 
$\rho=$ Tapped density,

$\rho_{0}=$ Bulk density

\section{Percentage azathioprine loading}

There were $50 \mathrm{mg}$ azathioprine loaded beads were thoroughly crushed and placed in a volumetric flask (Borosil ${ }^{\circledR}$ ) containing $50 \mathrm{ml}$ of $7.4 \mathrm{pH}$ phosphate buffer for $1 \mathrm{~h}$. Azathioprine was completely extracted from beads to buffer solution by filtration (pore size $11 \mu$ ).

The sample from the solution was taken to analyze spectrophotometrically at $\lambda_{\max } \mathrm{nm}$. The percentage azathioprine loading was calculated using Eq. 8 [8]:

$\%$ Azathioprine loading $=\left(\frac{\text { Actual azathioprine content }}{\text { Theoreticalazathioprine content }}\right) \times 100(8)$

\section{Scanning electron microscopy of uncoated beads}

The surface morphology and uniform shape of the prepared uncoated and eudragit S100 coated beads were studied using scanning electron microscope (Jeol JSM-6380LV, Japan). The eudragit S100 coated beads were cut into two halves with the help of a sharp cutter, SEM study of the cross-section area of eudragit S100 coated beads also showing coating thickness. The samples of beads were placed in sample holders and coated with platinum. The samples were imaged using a $5 \mathrm{kV}$ electron beam [9].

\section{In vitro azathioprine release profile}

In vitro release study was used to generate percentage cumulative azathioprine release profile of azathioprine loaded beads and to identify the retention of azathioprine in upper GI Tract and release in the colon. A dissolution study was carried out in $0.1 \mathrm{~N} \mathrm{HCl}$ solution ( $\mathrm{pH}-1.2)$, Phosphate buffer ( $\mathrm{pH}-6.8$ and 7.4) using USP type I (basket type, Electro Lab, Mumbai, India) dissolution apparatus to determine azathioprine release rate.

Accurately weighed beads were wrapped in a muslin cloth and placed in $0.1 \mathrm{~N} \mathrm{HCl}$ solution (pH-1.2) as dissolution media for $2 \mathrm{~h}$ which would be replaced with phosphate buffer pH-6.8 for $3 \mathrm{~h}$. Process parameters such as the volume of dissolution medium, the temperature of dissolution medium and rotation speed were kept $900 \mathrm{ml}, 37^{\circ} \mathrm{C}$, and $100 \mathrm{rpm}$, respectively during the study.

A sampling of $10 \mathrm{ml}$ was carried out at the interval of every 60 min and analyzed in UV visible double beam spectrophotometer in $0.1 \mathrm{~N} \mathrm{HCl}$ solution (pH-1.2). A sampling of $10 \mathrm{ml}$ was carried out at the interval of every $10 \mathrm{~min}$ and analyzed in UV visible double beam spectrophotometer in phosphate buffer pH-6.8 [9].

\section{Determination of coating efficiency}

There were $100 \mathrm{~g}$ of prepared beads were coated with $15 \%$ eudragit S100 solution in fluid bed coater for various time. The coating efficiency was determined by Eq. 9 [10].

$$
\% \text { Coating efficiency }=\left(\frac{\text { Actual weight gain }}{\text { Theoretical weight gain }}\right) \times 100(9)
$$

\section{Dissolution kinetic study}

Dissolution kinetic study was assessed for various kinetics like zero order, first order, Higuchi model, Hixon-Crowell model and, Korsmeyer/Peppa's model and their correlation coefficient (R) square values were noted. The best model fit was selected, which had the smallest sum of squared residual value $[11,12]$.

\section{Stability study}

Azathioprine loaded beads of the optimized batch were subjected to accelerated stability studies in aluminum/aluminum pouch pack as the aluminum strip is considered the best protecting packaging material but in the present study, the simulation was made using aluminum foil pouch. As the dosage form is formulated for sitespecific drug delivery to the colon, no change should occur in its drug dissolution profile. The beads of batch D3 were packed in the aluminum pouch and charged for accelerated stability studies at 40 ${ }^{\circ} \mathrm{C}$ and $75 \% \mathrm{RH}$ for $3 \mathrm{mo}$ in a humidity jar (Remi equipment, Mumbai, India). Azathioprine dissolution profile of exposed samples was carried out [9].

\section{Statistical analysis}

All data were represented as mean \pm SD of three independent experiments. The Wilcoxon test followed by the Dunnett's multiple comparison tests (considering false discovery rate $[q]>3.532$ as a significant level) were performed for in vitro dissolution profile between $0.1 \mathrm{~N} \mathrm{HCl}$ after $2 \mathrm{~h}$ and in phosphate buffer $\mathrm{pH} 6.8$ after $3 \mathrm{~h}$ and in vitro dissolution profile of optimized batch in $0.1 \mathrm{~N} \mathrm{HCl}$ after 2 $\mathrm{h}$ between uncoated (A8) and coated (D3) beads. Instant, GraphPad Inc., USA was used for statistical analysis. The results were considered as significant $95 \%$ of confidence level [13].

\section{RESULTS}

Azathioprine had $279 \mathrm{~nm} \lambda_{\max }$ in $0.1 \mathrm{~N} \mathrm{HCl}$ solution (pH-1.2) and phosphate buffer (pH-6.8, $\mathrm{pH}-7.4)$. The equation for calibration curve were $\mathrm{y}=0.045 \mathrm{x}+0.021\left(\mathrm{R}^{2}=0.997\right), \mathrm{y}=0.037 \mathrm{x}+0.027\left(\mathrm{R}^{2}=\right.$ $0.995)$, and $y=0.0379 x+0.0319\left(R^{2}=0.9959\right)$ in $0.1 \mathrm{~N} \mathrm{HCl} \mathrm{solution}$ (pH-1.2) and phosphate buffer ( $\mathrm{pH}-6.8$ and $\mathrm{pH}-7.4)$ respectively.

In differential scanning calorimetry study of a physical mixture of azathioprine and excipients (fig. 1), the pick was observed at $245^{\circ} \mathrm{C}$, which is the peak of azathioprine.

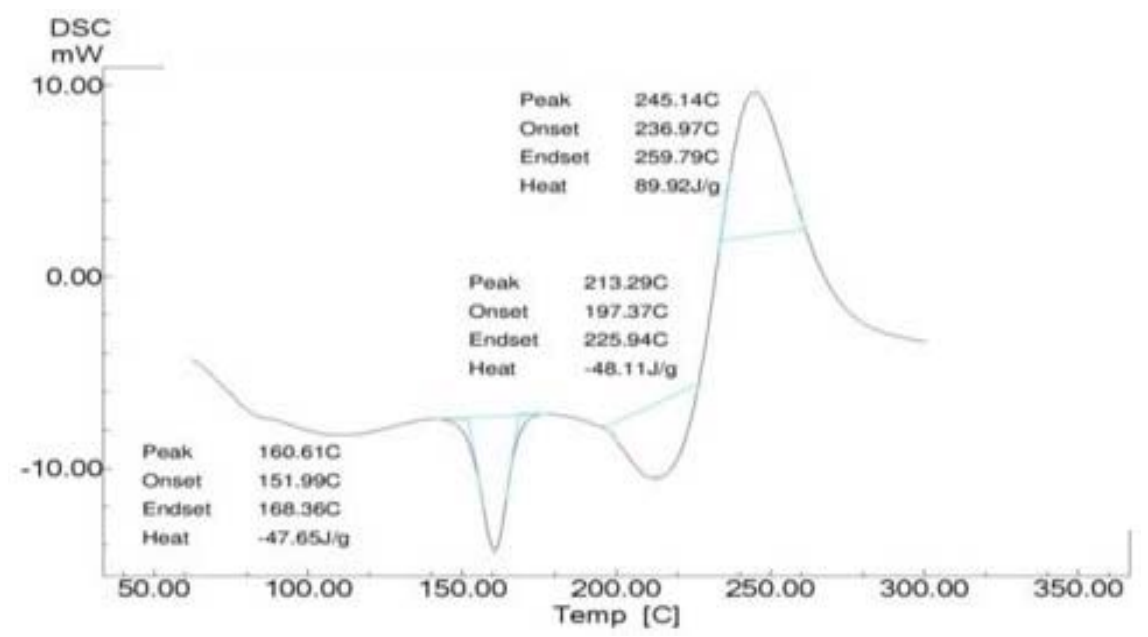

Fig. 1: Differential scanning calorimetry of a physical mixture of azathioprine and excipients. Acquisition weight: $3.22 \mathrm{mg}$, Atmosphere: Nitrogen, Flow rate: $20 \mathrm{ml} / \mathrm{min}$, Temperature: $10-350^{\circ} \mathrm{C}$ 
FTIR of a physical mixture of azathioprine and excipients (fig. 2) had been shown peaks at $3191.33 \mathrm{~cm}^{-1}, 2966.67 \mathrm{~cm}^{-1}, 2810.38 \mathrm{~cm}^{-1}$, and $1576.86 \mathrm{~cm}^{-1}$ which are major bands due to stretching's of NH group and purine ring of azathioprine respectively.
Scanning electron microscopy of an uncoated (A8) and coated optimized (D3) batches of beads were indicated the smooth and uniform surface (fig. 3A and B).

Evolution results of azathioprine loaded beads are represented in table 2 .

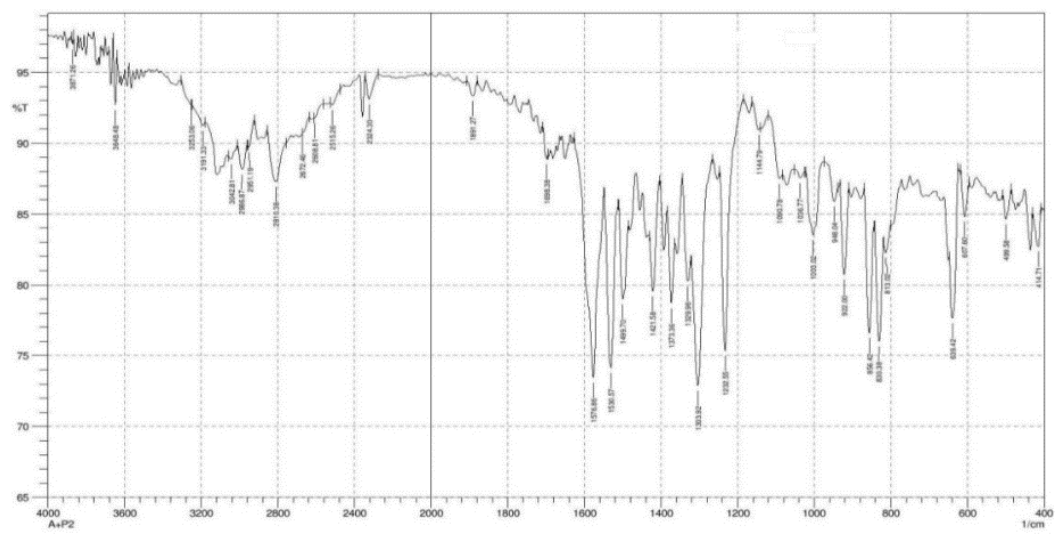

Fig. 2: Fourier transform infrared spectroscopy of a physical mixture of azathioprine and excipients

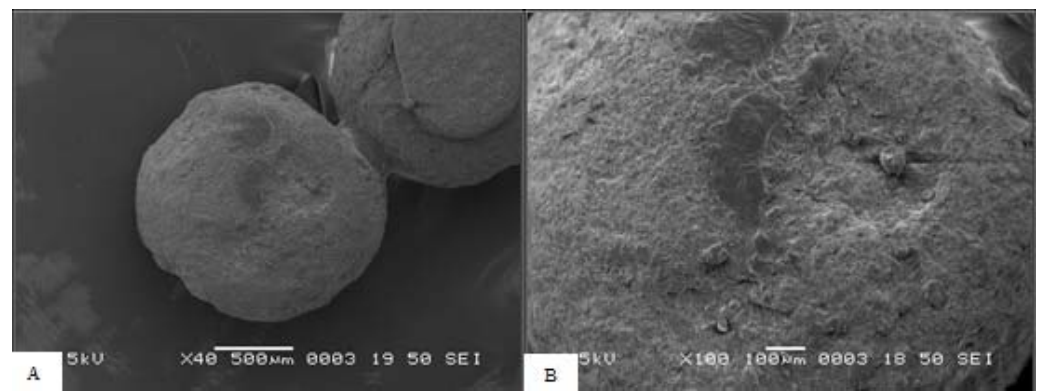

Fig. 3: Scanning electron microscopy of an uncoated optimized batch of beads. A: Uncoated optimized batch (A8). B: eudragit S100 coated optimized batch (D3)

Table 2: Evaluation results of beads

\begin{tabular}{|c|c|c|c|c|c|c|c|c|}
\hline Batch no. & $\%$ Yield & $\begin{array}{l}\text { Average mean diameter } \\
(\mathrm{mm})\end{array}$ & $\begin{array}{l}\text { LOD } \\
\text { at } 105^{\circ} \mathrm{C}\end{array}$ & $\begin{array}{l}\text { Swelling } \\
\text { index }\end{array}$ & $\begin{array}{l}\text { Compressibility } \\
\text { index }(\%)\end{array}$ & $\begin{array}{l}\text { Bulk } \\
\text { density } \\
(\mathrm{g} / \mathrm{ml})\end{array}$ & $\begin{array}{l}\text { Tapped } \\
\text { density } \\
(\mathrm{g} / \mathrm{ml})\end{array}$ & $\begin{array}{l}\text { Hausner's } \\
\text { ratio }\end{array}$ \\
\hline A1 & $64.13 \pm 3.13$ & $1.211 \pm 0.74$ & $86.34 \pm 0.58$ & $2.358 \pm 0.12$ & $32.79 \pm 1.12$ & $0.662 \pm 0.01$ & $0.985 \pm 0.03$ & $1.49 \pm 0.09$ \\
\hline $\mathrm{A} 2$ & $70.25 \pm 5.53$ & $1.193 \pm 0.86$ & $85.97 \pm 0.46$ & $2.385 \pm 0.13$ & $34.11 \pm 1.13$ & $0.649 \pm 0.02$ & $0.985 \pm 0.04$ & $1.52 \pm 0.08$ \\
\hline A3 & $71.23 \pm 4.15$ & $1.186 \pm 0.79$ & $86.46 \pm 0.51$ & $2.556 \pm 0.14$ & $28.07 \pm 1.21$ & $0.656 \pm 0.01$ & $0.912 \pm 0.03$ & $1.39 \pm 0.07$ \\
\hline A4 & $78.61 \pm 0.92$ & $1.194 \pm 0.16$ & $84.74 \pm 0.28$ & $2.425 \pm 0.15$ & $19.54 \pm 1.25$ & $0.696 \pm 0.02$ & $0.865 \pm 0.02$ & $1.24 \pm 0.06$ \\
\hline A5 & $85.32 \pm 1.87$ & $1.175 \pm 0.27$ & $85.37 \pm 0.31$ & $2.521 \pm 0.16$ & $17.93 \pm 1.27$ & $0.705 \pm 0.03$ & $0.859 \pm 0.01$ & $1.22 \pm 0.05$ \\
\hline A6 & $84.27 \pm 2.15$ & $1.181 \pm 0.19$ & $83.52 \pm 0.32$ & $2.495 \pm 0.17$ & $18.84 \pm 1.11$ & $0.702 \pm 0.04$ & $0.865 \pm 0.02$ & $1.23 \pm 0.04$ \\
\hline A7 & $86.15 \pm 0.89$ & $1.219 \pm 0.85$ & $85.28 \pm 0.23$ & $2.546 \pm 0.18$ & $15.21 \pm 1.01$ & $0.708 \pm 0.05$ & $0.835 \pm 0.03$ & $1.18 \pm 0.04$ \\
\hline $\mathrm{A} 8^{*}$ & $88.19 \pm 1.19$ & $1.201 \pm 0.19$ & $83.36 \pm 0.20$ & $2.654 \pm 0.19$ & $17.08 \pm 1.02$ & $0.699 \pm 0.04$ & $0.843 \pm 0.02$ & $1.21 \pm 0.05$ \\
\hline
\end{tabular}

*Optimized batch; LOD: Loss on drying. Data were represented as mean \pm SD, $n=3$.

Table 3: Results of in vitro azathioprine release profile

\begin{tabular}{|c|c|c|c|c|c|}
\hline \multirow[t]{2}{*}{ Batch No. } & \multirow[t]{2}{*}{$\begin{array}{l}1 \text { (\% CAR in } \\
0.1 \mathrm{~N} \mathrm{HCl} \text { after } 2 \mathrm{~h})\end{array}$} & \multirow[t]{2}{*}{$\begin{array}{l}2 \text { (\% CAR in phosphate buffer } \\
\text { pH } 6.8 \text { after } 3 \mathrm{~h})\end{array}$} & \multirow[t]{2}{*}{$\begin{array}{l}3 \text { (Total } \\
\% \text { CAR after } 5 \text { h) }\end{array}$} & \multicolumn{2}{|l|}{$\begin{array}{l}\text { SA } \\
2 \text { vs } 1\end{array}$} \\
\hline & & & & p-value & q-value \\
\hline$\overline{\mathrm{A} 1}$ & $33.29 \pm 1.31$ & $62.75 \pm 2.31$ & $96.04 \pm 2.48$ & 0.0039 & 5.551 \\
\hline A2 & $30.17 \pm 1.22$ & $66.91 \pm 2.45$ & $97.08 \pm 3.11$ & & \\
\hline A3 & $29.12 \pm 1.14$ & $67.36 \pm 1.75$ & $96.48 \pm 2.24$ & & \\
\hline $\mathrm{A} 4$ & $23.41 \pm 0.88$ & $74.71 \pm 1.65$ & $98.12 \pm 1.12$ & & \\
\hline A5 & $33.83 \pm 1.42$ & $64.35 \pm 1.42$ & $98.18 \pm 2.84$ & & \\
\hline A6 & $31.73 \pm 1.62$ & $65.87 \pm 2.16$ & $97.60 \pm 2.27$ & & \\
\hline A7 & $30.17 \pm 1.48$ & $65.98 \pm 1.64$ & $96.15 \pm 3.83$ & & \\
\hline $\mathrm{A}^{*}$ & $24.97 \pm 1.15$ & $73.09 \pm 1.26$ & $98.06 \pm 2.14$ & & \\
\hline D3⿻ & $3.24 \pm 0.02$ & $12.45 \pm 0.16$ & $99.64 \pm 1.15$ & & \\
\hline
\end{tabular}

*Uncoated optimized batch; "Eudragit S100 coated optimized batch, Data were represented as mean \pm SD, $\mathrm{n}=3$, CAR: Cumulative azathioprine release, SA: Statistical analysis, $p<0.05$ and $q>3.532$ were considered as significant. 
There was maximum azathioprine release observed in phosphate buffer (pH 6.8) after $3 \mathrm{~h}$ (table 3).

Eudragit S100 coating was decreased release of azathioprine release in $0.1 \mathrm{~N} \mathrm{HCl}$ after $2 \mathrm{~h}(\mathrm{p}=0.049, q=3.533)$.
In dissolution kinetic study $\mathrm{R}^{2}$ value for zero order, first order, Higuchi model, Hixon-Crowell model and, Korsmeyer/Peppa's model were $0.763,0.7,0.649,0.688$, and 0.892 respectively. In vitro percentage cumulative azathioprine release was identical before and after stability study (fig. 4).

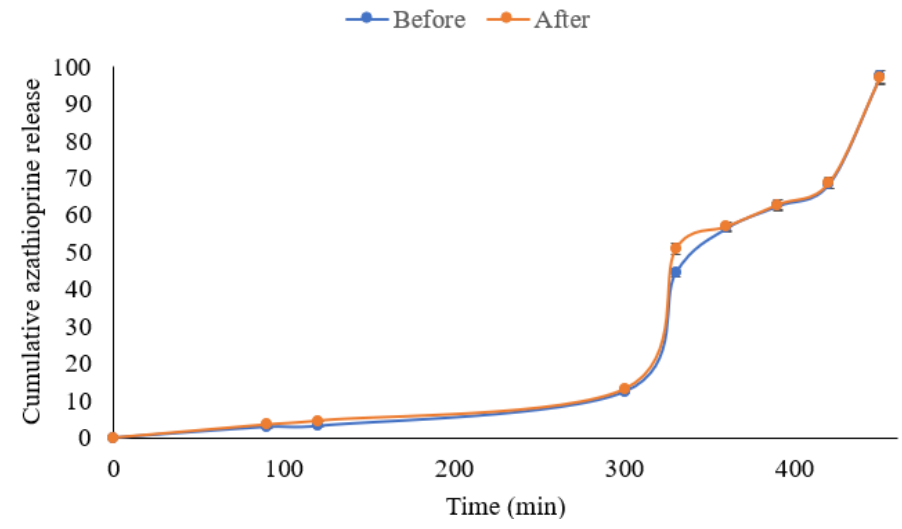

Fig. 4: Stability study of Eudragit S100 coated optimized batch. Data are represented as mean \pm SD of five independent experiments

\section{DISCUSSION}

Azathioprine had been shown linearity in the rage of 4-15 $\mu \mathrm{G} / \mathrm{ml}$, 5$20 \mu \mathrm{G} / \mathrm{ml}$, and $4-20 \mu \mathrm{G} / \mathrm{ml}$ in $0.1 \mathrm{~N} \mathrm{HCl}$ solution $(\mathrm{pH}-1.2)$ and phosphate buffer (pH-6.8 and pH-7.4) respectively. DSC and FTIR had identical peaks with that of pure azathioprine in compatibility study. The study was shown that there was no chemical interaction between excipients and azathioprine [14].

Results of in vitro azathioprine release were indicated more azathioprine release found in phosphate buffer (pH-6.8). Pectin$\mathrm{CaCl}_{2}$ beads are provided pH-dependent drug release [15]. With respect to the results of in vitro results, the study was succeeded in $\mathrm{pH}$-dependent azathioprine delivery.

$\mathrm{R}^{2}$ the value was maximum in Korsmeyer/Peppa's model. Release exponent (n) was higher than 1 . The optimized formulation was followed super case II transport diffusion mechanism $[11,12]$. With respect to the results of dissolution kinetic study, the study was succeeded in colon targeted azathioprine delivery.

Dissolution profile, before and after accelerated stability study for D3 had found satisfactory and no deviation from normal results. The study was prepared stable coated beads of azathioprine.

\section{CONCLUSION}

The in vitro experimental study had been succeeded in development and optimization of stable calcium-pectinate beads of the azathioprine-a multi-particulate dosage form for the effective treatment of inflammatory bowel disease. The finding provided beads of azathioprine, which had maximum azathioprine release in $\mathrm{pH} 6.8$.

\section{ACKNOWLEDGEMENT}

Authors are thankful for teaching and non-teaching staff of RK University who made the study successful.

\section{FUNDING}

The study did not receive any fund from the private, commercial or non-profit sector.

\section{AUTHORS' CONTRIBUTION}

Samir A. Atara had performed the experiment and written the manuscript for intellectual content. Moinuddin Soniwala had guided the study and collected the data.

\section{COMPETING INTERESTS}

Authors have disclosed that they have no any conflict of interest or the other interest regarding results/discussion reported in the study.

\section{REFERENCES}

1. Bourgeois S, Gernet M, Pradeau D, Andremont A, Fattal E. Evaluation of critical formulation parameters influencing the bioactivity of beta-lactamases entrapped in pectin beads. Int J Pharm 2006;324:2-9.

2. Chourasia MK, Jain SK. Pharmaceutical approaches to colon targeted drug delivery systems. J Pharm Pharm Sci 2003;6:3366.

3. Saffran M, Kumar GS, Savariar C, Burnham JC, Williams F, Neckers DC. A new approach to the oral administration of insulin and other peptide drugs. Science 1986;233:1081-4.

4. Adetunji LR, Adekunle A, Raghavan VV. Advances in the pectin production process using novel extraction techniques: a review. Food Hydrocolloid 2017;62:239-50.

5. Mori NM, Patel P, Sheth NR, Rathod LV, Ashara KC. Fabrication and characterization of film-forming voriconazole transdermal spray for the treatment of fungal infection. Bull Fac Pharm (Cairo Univ) 2017;55:41-51.

6. Andonova V, Georgiev G, Dimitrova S, Katsarova M, Kassarova M. Characterization, in vitro evaluation and stability studies of indomethacin-loaded polyzwitterionic copolymer nanoparticles. Int J Drug Dev Tech 2014;5:89-97.

7. Santagapita PR, Mazzobre MF, Buera MP. Formulation and drying of alginate beads for controlled release and stabilization of invertase. Biomacromolecules 2011;12:147-55.

8. Vishwakarma N, Ganeshpurkar A, Pandey V, Dubey N, Bansal D. Mesalazine-probiotics beads for acetic acid experimental colitis: formulation and characterization of a promising new therapeutic strategy for ulcerative colitis. Drug Delivery 2015;22:94-9.

9. Mennini N, Furlanetto S, Maestrelli F, Pinzauti S, Mura P. Response surface methodology in the optimization of chitosanCa pectinate bead formulations. Eur J Pharm Sci 2008;35:1825.

10. Murata Y, Miyashita M, Kofuji K, Miyamoto E, Kawashima S. Drug release properties of a gel bead prepared with pectin and hydrolysate. J Controlled Release 2004;95:61-6.

11. Ramteke KH, Dighe PA, Kharat AR, Patil SV. Mathematical models of drug dissolution: a review. Sch Acad J Pharm 2014;3:388-96.

12. Andonova V, Georgiev G, Toncheva V, Petrova N, Karashanova $\mathrm{D}$, Penkov $\mathrm{D}$, et al. Indomethacin loading and in vitro release properties from vinyl acetate homo-and copolymer nanoparticles, coated with polyzwitterion and carbopol ${ }^{\circledR}$ shells. Int J Pharm Pharm Sci 2014;6:691-9.

13. Bakhle SS, Avari JG. Development and characterization of solid self-emulsifying drug delivery system of cilnidipine. Chem Pharm Bull (Tokyo) 2015;63:408-17. 
14. Singh BN, Kim KH. Characterization and relevance of physicochemical interactions among components of a novel multi particulate formulation for colonic delivery. Int J Pharm 2007;34:143-51.
15. Dhalleine C, Assifaoui A, Moulari B, Pellequer Y, Cayot P, Lamprecht $\mathrm{A}$, et al. Zinc-pectinate beads as an in vivo selfassembling system for pulsatile drug delivery. Int J Pharm 2011;414:28-34. 